\title{
INCREASING STUDENTS' ENGAGEMENT IN LISTENING THROUGH STRATEGY-BASED INSTRUCTION
}

\author{
Suyono \\ Program Studi Tadris Bahasa Inggris Jurusan Tarbiyah STAIN Batusangkar \\ Korespondensi: Komplek TPI, blok F No. 7, Rambatan, Batusangkar, Sumatera Barat \\ e-mail: sotesol@gmail.com
}

\begin{abstract}
Strategy-based instruction is believed to able to improve students' involvement in learning, including learning listening. Unfortunately, the lack concept of the instruction and the less training that the students have causes them still struggling in learning listening. This research report is aimed at investigating the effectiveness of using strategy-based instruction in term of students' involvement and students' comprehension in listening. This is a classroom action research of which the researcher and the teacher worked collaborately in implementing the strategybased instruction. The research was done in two cycles of which each cycle was realized in three meetings. The data were collected using questionnaire and test. The finding suggests that the strategy-based instruction improve students' learning in term of involvement and comprehension. The involvement in learning listening raised in all aspects of strategies which include cognitive, metacognitive and socioaffective strategies which reaches 30,3\%. The improvement in term of involvement also affects the improvement in students' comprehension from the average of 47 in the beginning of the study to 73 or $53 \%$ at the end of the.
\end{abstract}

Key words: Students engagement, learning strategy, strategy based instruction

\section{INTRODUCTION}

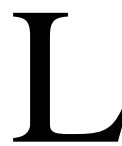

istening is widely viewed as the most difficult skill to approach in foreign language learning (O'Malley, Chamot, \& Kuper, 1989; Vandergrift, 2004). Compared to other skills, such as reading or writing, which allow the language learners to have some degree of control over the process, listening only provides little, if any, control with which the learners to intervene. Once they miss part of the aural message while listening, they are very unlikely to return to that missing part without losing more parts of the input. While for the sake of learning, they may ask the teacher to repeat the missing part of the recording in a classroom setting, real life listening such as listening to news from $\mathrm{CNN}$ or $\mathrm{BBC}$ channels does not allow this control. Therefore, listening is a very complicated process for many learners to engage in.

Some of the difficulties associated with listening which make listening is so complicated are pace and accent of the speakers, text load and level characteristics, learners' insufficiency of language and content knowledge and task and process characteristics (Rubin, 1994; Vogely, 1998). An unfamiliar accent used by the speaker in conjunction with high speech would definitely cause problems with listening. This will be further complicated when the text and task types are beyond the learners' linguistic and 
real world knowledge and training of listening strategies. Yet, knowing what to listen for and how is believed to relieve, to a certain degree, the complicated matter of listening. Therefore, training the learners to familiarize themselves with text and task types of listening and some strategies to approach them would be badly needed (Carrier, 2003; Cross, 2009; O'Malley, et al., 1989).

There is doubt whether strategies for listening exist and are thus teachable. Ridgway (2000) is one who argues that strategy is something subtle and people may not realise whether they are applying a particular strategy while listening. Furthermore, he maintains that having the learners aware of what is going on while they are listening to particular aural input would place greater burdens upon the students and is unrealistic; on one hand, they have to extract the meaning of the incoming input and on the other; they have to recognise the label of the strategies they may apply. In addition, Field $(1998,2000)$ suggests that students' differences in temperament and whether the strategies meet students needs in long term use are other concerns raised to respond the trend of strategy instruction. Chen (2007) and Liu and Goh (2006) also suggest that some students are reported not to receive any benefit from strategy instruction and state that such instruction is useless.

Despite some concerns regarding strategy training in listening, most researchers in listening strategies maintain that strategy can be taught to the learners. The only difference is whether strategy instruction should be taught explicitly or implicitly and whether it should be embedded or at a direct level (Carrier, 2003; Chamot, 2005). In embedded and implicit instruction, the teacher guides the students through a listening activity without letting them know that a particular listening strategy is being put into action. On the other hand, explicit or direct instruction of listening strategy teaches the learners the label of the strategy and how it works. Chamot and Thompson (2005) and Rubin (1996) suggest that explicit instruction of listening strategies is more effective in boosting learners' listening fluency compared to the implicit instruction as it enables learners to transfer such knowledge to other contexts. Therefore, it is a gift for the students to have such training as their listening fluency might be enhanced.

A wide array of strategies in learning a foreign language have been identified by scholars, namely cognitive and metacognitive strategies. Cognitive strategies are directly responsible for making sense of the incoming listening input, metacognitive strategies support the cognitive endeavour by planning, monitoring and evaluating the process of attending the inputs (O'Malley, et al., 1989). In addition, socio-effective strategies are other determining factors which indirectly also support the process of sensing the aural input. (Bacon, 1992; Chamot, 2005; Oxford \& Crookall, 1989). The following discussing highlights some strategies that most scholars suggest for learners in listening.

STAIN Batusangkar as one of tertiary level of education which has English department provides its students with subjects in Listening. There are four consequtives Listening subjects started from semester one to semester four. The subjects are expected to improve students' fluency in Listening in particular and the whole English proficiency in general.

Despite the support at the policy level, the students seem to suffer from insufficient listening proficiency. This is due to a number of reasons. Scarce 
materials for listening are considered to be the most cause of the deficiency.There were no particular materials which the students may use throughout the semester. Another source of problem is the instructional approach the lecturer use in the classroom. There was a tendency of which teaching listening is not really teach the students. Rather, it merely tests the students. Consequently, the students may not really learn how to listen, instead, a regular hour where testing is taking place. Another consequency is that the students may not really involve the way to listen the materials. Therefore, listening instruction which allows learners to build up listening fluency and guides them to raise and develop their awareness of listening strategies is desperately needed. This research article answer the following question: Do Strategy Based Instruction increase students' involvement in Listening?

\section{METHODOLOGY}

This is an action research of which the subject in question got ways of improving their engagement in learning listening through strategy-based instruction. This research was conducted to English Students of STAIN Batusangkar who took Listening 3 in the 2011/2012 academic year. The total number of the students were 101 which were grouped into three classes; group A, B and C. Each class consisted of 32, 35 and 33 respectively. This research focused on one of the classes of which the students' involvement and achievement in listening is considered lower compared to the others. For selecting the focus of the study, the researcher consulted to the lecturer for the averall track record of the students in term of involvement in the previous Listening subjects and their averall score of the subject. In addition, they were also assigned to do pre test so that the past information and the current situation really went together.

This research was conducted following the common model of classroom action research which includes planning, action, monitoring and evaluation, and recycle until sufficient conclusion is drawn (Burns, 1995; Syamsudin \& Damajanti, 2006). In planning the instruction, the researcher designed syllabus and determine what strategies were introduced to the students. Then, a lesson planning for each meetings of which altogether were six lesson plans. For each of the lesson plans, there were some supporting handouts or worksheet for the sake of the lesson.

In implementing the lesson plans, the researcher and the co-lecturer took turn conducting the teaching. In the first three meeting, the teaching was delivered by the researcher. While in the last three meetings, the co-lecturer did it as she was assumed to get to use to do such instruction. Throughout the study, the researcher and the co-lecturer discussed the implementation of the plan and drew some ideas for reflection and improvement of the next meetings.

To collect the data, questionnaire and test were applied. Questionnaire was used to seek information about students involvement in pre, whilst and past listening activities. The questionnaire included information on students' cognitive, metacognitive and socioaffective strategy inventory during the proses. Test was administered to gather information in term of the initial proficiency of the students listening comprehension and how their comprehension might improve after following the series Listening lesson using the SBI. The data from the questionnaire were analised using simple descriptive statistic and compared the result of the quantification from the precircled, end of circle 1 and end of circle 2 data to see if improvement took place. 
Similarly, the data from the tests were also quantified using descriptive statistic and used the result to see whether improvement on Listening comprehension was apparent.

\section{Findings}

Engagement in learning may be seen from three different aspects, namely cognitive, meta-cognitive and socioaffect resources. Engagement in cognitive aspect refers to how learners use their cognitive capital to approach particular learning tasks by categorizing, inferencing, organising or contextualizing the the learning input. Engagement using meta-cognitive aspect means the endeavours the learners spend to deal with the learning inputs by planing, monitoring, evaluating and such. Meanwhile, socio-affective engagement involves the investment of feeling and others to help the learners to approach to the learning. While the first two aspects are mostly invisiable, the latter might be feaseble.

Using questionnaire to gather information of the students' engagement in Listening on those three different aspects, this research study revealed that the learners in question had already invested those aspects and the degree of the engagement was increasing due to the introduction of the strategy-Based Instruction.

\section{Pre-Circle}

To see the initial knowledge and application of those three aspects of learning strategies in Listening, the respondents of this research were assigned to fill the strategy inventory questionnaire (henceforth, SIQ). They were also assigned to follow pre-test. The data from the first SIQ showed that the average students score was 3,3. While for the averall score for each aspect of the students' learning strategy was 3,44 for metacognitive strategy, 3,21 for cognitive startegy and 3,88 for socio-affective strategy. All of those scores were considered medium in term of used and aplication (Oxford, 1989).

In contrast to the strategies inventorily used by the respondent which was considered medium, the students' score in term of listening comprehension at the pre test session was considered low. The score was 47 .

\section{Circle 1}

a. Planning

Learning from the data of the first SIQ of which the students' engagement in Listening was not significantly high, the particular steps should be done to increase their envolvement in Listening. Therefore, the researcher planned particular strategies for teaching how to listen the aural input( see appendix 1).

There were 17 strategies which were planned to be introduced throughout the first three meetings. In the first meeting, there were 8 strategies which include setting goal in listening, activating background knowledge, note taking, selective attention, cooperating with peers, paying attention, peers counseling, and clarifying to the proficient listeners. In the second meeting, the students were introduced with making an outline and making summary strategies, while in the third meeting, making prediction, ask question, making inferencing, focus attention and building a big picture strategies were introduced.

Together with the planning of the lesson, the researcher also planned the lesson planned for each meeting which informs the standard competence, core competence, indicatators, lesson objectives, materials, teaching approaches, teaching procedures and 
assessment policy. Each of the lesson plan was also accompanied by worksheet or handout for the students which contains series of works have to be done during the lesson.

b. Action

\section{1) First Meeting}

The first meeting was done on Friday at $14.05-15.45$ on September 21, 2011. The student were about to learn listening to narative text which was about some one someone called Yusuf Estes who became a Muslim. He told that he was a former Christian Minister but later converted to be a Muslim after having bussines with a man from Egypt. After series of events he experienced and discussion with the man, he eventually left his former religion and turned into Islam.

In order to comprehend the text, the students were introduced to some strategies as stated in the plan and how to apply such strategies while listening to the text. They were taught how to use the strategies before listening to the text, whilst and after listening to the text.

In addition, while applying the strategies, they were given three times to listen to the recording. As suggested by Vandergrift (2004), the first listening was given to allow the learners to oreint themselves with text, the second listening was to very the details of the text, while the third listening was given to alow the students to reconstruct or synthesize the whole information of the recording.

2) Second meeting

In the second meeting which was done on Friday, at 14.05 15.45 on September 30, 2011, the students were still learning to listen to the narative text. As the material from the first meeting a bit long for the students to listen to the whole text, it was continued to the second meeting. Therefore, there was no separate worksheet from the first meeting worksheet, except that the details of the infromation was continued.

The procedures for teaching in the second meeting were similar to the first one of which the new two listening strategies; making outline and making summary were conceptually and practically introduced and the students were also be given three times to listening. After listening to the recording three times, the students were assigned to practice making outline and making summary.

3) Third meeting

In the third meeting which was done on Friday at 14.05-15.45 on October 7, 2011, the students were about to learn listening to monologue descriptive text. The text was about the description of the relationship between gender and kind of job in particular hospital in Sydney. The description is said to be in a table of which gender and kinds of job in are colums and numbers related to the occupation are in rows. The narator also provides the comparison of those male and female differences and give conclusion of the table.

As particular text may be approached differently to others, in this meeting the students were introduced to seven new listening strategies which were mostly appropriate to the descriptive texts. The strategies included making prediction, ask question, making inferences, focus attention, building big picture and bilding imagery. In addition, the students were also told 
to apply the relevant already-taught strategies from the previous weeks.

Moreover, the procedures for listening to the text remained similar to the prevoius weeks. The students were help to familiarize the the fore going text in the prelistening session, and were given three times to listen to the recording so that they could orient, verify and reconstructing the text in the whilst listening activity and doing evaluation by making summary in the post listening activity.

c. Monitoring

While implementing the SBI throughout the first to the third meeting, the researcher and the colecturer did monitoring the process. Some ways which were done to monitor the process include walking around to see if the students wrote something on the worksheet to indicate the application of the taught strategies, observing peer discussion if they were told to do so, reading the students' facial expression if they were understood with the explained and applied strategies and so.

From the monitoring process throughout the first three meetings, it was found that some students were eagerly applied almost the whole process of the instruction. It was proven by the filling of their worksheet of which it might reflect their engagement in the learning. However, some students showed otherwise.

d. Evaluation

Having implemented the SBI in the first circle, the researcher administered SIQ for the second time which was done in the last 20 minute of the third meeting. The aim of this queationnaire was to see how the studens make use of the afore taught strategies and to see if improvement in term of metacognitive, cognitive and socio-afftective strategies might take place.

The data from the second SIQ revealed that the averall score for strategy invesment was 3,8. This score was considered high based on the band score criteria as suggested by Oxford (1989). For the individual aspect of the strategy, it was shown that meta conitive strategy was 3,9 , cognitive and socio-affective strategy were 3,62 and 3,98 respectively. These individual scores were also considered high. Compared to the first SIQ data of which the averall score was 3,3 and the individual score was $3.44,3.21$, and 3.38 for meta cognitive, cognitive and socio-affective strategies respectively, there was an improvement of the startegic investment spent by the students in listening. There was an average increase of $14,3 \%$ for the whole strategy engagement. While for the average increase of the individual aspect of strategic investment was $13,7 \%$ for meta cognitive strategy, 12 , $8 \%$ for cognitive strategy and 17,8 for socio-affective strategy.

Apart from those improvement in term of strategy engagement gained from the SIQ data, the researcher found that some students still had difficulties in appliying some strategies. It was shown from their worksheets of which some points were still blank. In addition, time alocation for completing the worksheet was another issue. Therefore, these problem were addressed in the second circle.

\section{Circle 2}

a. Plan

Planning for the second round of the study was focused on two aspect, namely, keep implementing the 
already taught strategies and introducing new strategies to the students. In implementing the alreadytaught strategies, it was planned that the students got fair opportunity in using them particularly those that are used in pre-listening activities. Meanwhile, for the new strategies which include making prediction, making use of context, checking dictionnaire, structured reviewing, building confidence and making positive impact were only planned on the fourth and five meetings, while on the last meeting was not used to introduced any new strategies. Instead, it was planned to allow students to get practice on applying the whole strategies. In addition, one more meeting was to administered post test, filling the last questionnaire and writing a think aloud protocol.

b. Action

1. Fourth meeting

This meeting was conducted on Friday, 14 October 2011 at $14.05-15.45 \mathrm{pm}$. The listening input was about another descriptive text which describes the population growth of Australia since the beginning of twentieth century. The description which was told to be the line chart showed that there had been three periods of population development, namely, the first forty years of the century of which the growth was steadily increase, the rapid increase since the end of second world war till 1980s and the level off increase of the last decade of the century. Meanwhile, for the new strategies which were introduced in the meeting were, making prediction and making use of context.

Similar to the previous meeting of this study, the process of intruction was conducted into three consequtive listening activities; pre, whilst and listening activities. In the pre-listening activities, the students were allowed to implement setting goal, activating background knowledge, making prediction and asking question about the text in the whorkseet. They were also allowed to do those tasks whether with their peers or individual.

While in whilst listening activities, the students were given the opportunity to listen to the recording three times; first listening for text orientation, second listening for confirmation and third listening for reconstructing the general and specific ideas of the recording. This activities were done to allow the students to apply those already taught strategies which suit to be used to deal with the tasks. In addition, special attention of the application of the two new strategies were given in this stage. Finally, in the post listening activities, the students were assigned to make an outline of the recording and followed by making summary.

\section{Second meeting}

This meeting was done on Friday 21 October 2011 at 14.05 to 15.45. The listening material for this meeting was a report text. This text, which was taken from the VOA Special English Program, was about the health report. The narator of the report said that laughter could reduce mental stress which in turn it could reduce the risk of heart attack. Using the result of a research study as the basis of the report, she said that the effect of laughter was similar to the effect of excercise. However, the researcher did not suggest to replace excercise with laughter. Rather, he suggested that one should spend at least 15 
minutes per day with laughter to avoid mental stress.

Meanwhile for the new strategies, they were three strategies; building confidence, making positive impact and checking dictionnaire. Those three strategies were introduced mainly for resolving the common problems which use to appear in listening namely, affective factors of which the students had negative feeling of the listening input. By introducing those strategies, they might overcome such affective barriers. In addition, looking at dictionary for overcoming lexical problem while listening to the text was also introduced. Using those two particular problem solving strategies, it was expected that the students had enough strategies to deal with any tasks in listening..

While for the instruction process, it was done as the previous meeting of this study. There was three consequtive listening activities; pre, whilst and listening activities. In the pre-listening activities, the students were allowed to implement setting goal, activating background knowledge, making prediction and asking question about the text in the whorkseet. They were also allowed to do those tasks whether with their peers or individual.

In whilst listening activities, the students were given the opportunity to listen to the recording three times; first listening for text orientation, second listening for confirmation and third listening for reconstructing the general and specific ideas of the recording. This activities were done to allow the students to apply those already taught strategies which suit to be used to deal with the tasks. In addition, special attention of the application of the two new strategies were given in this stage. Finally, in the post listening activities, the students were assigned to make an outline of the recording and followed by making summary.

3. Third meeting

The last meeting of this study was done on Friday 28 October 2011. The listening input assigned for this meeting still about a health report taken from the same source of the second meeting. This time of the report was about the use of drug treatment to fight against breast cancer. The report from particular research study revealed that if breast cancerists were treated properly using particular drug, the cancer might be cured and the risk of the cancerists from coming back were also low. The report also mentioned other two ways of avoiding the cancer from coming back, namely low diet menu and phisical movement.

There was no new strategies were introduced in this meeting. Rather, the practice of the application of the whole strategies in dealing with listening input.

Instruction was conducted as it was which include three consequtive listening activities; pre, whilst and listening activities. In the pre-listening activities, the students were allowed to implement setting goal, activating background knowledge, making prediction and asking question about the text in the whorkseet. They were also allowed to do those 
tasks whether with their peers or individual.

In whilst listening activities, the students were given the opportunity to listen to the recording three times; first listening for text orientation, second listening for confirmation and third listening for reconstructing the general and specific ideas of the recording. This activities were done to allow the students to apply those already taught strategies which suit to be used to deal with the tasks. In addition, special attention of the application of the two new strategies were given in this stage. Finally, in the post listening activities, the students were assigned to make an outline of the recording and followed by making summary.

\section{c. Monitoring}

Throughout the second circle the researcher and the co-lecturer also did the monitoring the process. As it was done in the previous circle, the similar ways were done to monitor the process, namely, walking around to see if the students wrote something on the worksheet to indicate the application of the taught strategies, observing peer discussion if they were told to do so, reading the students' facial expression if they were understood with the explained and applied strategies and so.

From the monitoring process throughout the second three meetings, it was found that more and more students were eagerly applied almost the whole process of the instruction. It was proven by the filling of their worksheet of which it reflecedt their engagement in the learning. However, the researcher also still found that some students showed otherwise. Yet, the number of students who seemed confused to apply the strategies were relatively small, particularly in part of the whorksheet which showed details information of the recording.

d. Evaluation

Upon completing the SBI in the first second circle, the researcher administered post test, another SIQ, and think aloud technique of data gathering. Those three data gathering were done one week from the last meeting, exactly on Friday the 4th November, 2011 at usual time, 14.05 tp 15.45. The test was administered to see whether improvement in term of students' listening comprehension was taken place and the queationnaire was aimed to see if the studens make use of the already taught strategies and to see if improvement in term of metacognitive, cognitive and socioafftective strategies might also appear. Meanwhile, the think aloud technique was assigned to see how students might reflect the whole process in their own words.

The data from the post test using the similar test items from the pretest reveled that there was improvement in term of students mean score of the test. The result of the pre test mean score was 47 , while the post test mean score was 73 . The figures suggest that there was an increase in term of students score of which the increase reached $53 \%$.

Meanwhile, for the SIQ data from the pre-circle, the end of circle 1 and the end of circle 2 were presented in the following table. 
Table 1. The Average Increase of SIQ Data

\begin{tabular}{|c|c|c|c|c|c|c|c|}
\hline \multirow[b]{2}{*}{ NO } & \multirow[b]{2}{*}{$\begin{array}{c}\text { STRATEGY } \\
\text { ENGAGEMENT }\end{array}$} & \multicolumn{3}{|c|}{ CIRCLE } & \multicolumn{3}{|c|}{ INCREASE IN \% } \\
\hline & & PRE & $\begin{array}{c}\text { END } \\
1\end{array}$ & $\begin{array}{c}\text { END } \\
2\end{array}$ & $\begin{array}{c}\text { PRE } \\
- \\
\text { END } \\
1 \\
\end{array}$ & $\begin{array}{c}\text { END } \\
1- \\
\text { END } \\
2 \\
\end{array}$ & $\begin{array}{c}\text { PRE - } \\
\text { END } \\
2\end{array}$ \\
\hline 1 & WHOLE STRATEGIES & 3,3 & 3,8 & 4,3 & 15,2 & 13,2 & 30,3 \\
\hline 2 & META COGNITIVE & 3,44 & 3,91 & 4,44 & 13,7 & 13,6 & 29,1 \\
\hline 3 & COGNITIVE & 3,21 & 3,62 & 4,12 & 12,8 & 13,8 & 28,3 \\
\hline 4 & SOCIO-AFFECTIVE & 3,38 & 3,98 & 4,2 & 17,8 & 5,5 & 24,3 \\
\hline
\end{tabular}

The data revealed that the averall score for strategy invesment was 4.3. This score was considered high based on the band score criteria as suggested by Oxford (1989). For the individual aspect of the strategy, it was shown that meta cognitive strategy was 4.43 , cognitive and socio-affective strategy was 4.12 and 4.2 respectively. These individual scores were also considered high.

Compared to the second SIQ data of which the averall score was 3.8 and the individual score was $3.91,3.68$, and 3.98 for meta cognitive, cognitive and socioaffective strategies respectively, there was an improvement of the startegic investment spent by the students in listening. There was an average increase of $13.2 \%$ for the whole strategy engagement. While for the average increase of the individual aspect of strategic investment was $13.6 \%$ for meta cognitive strategy, $13.8 \%$ for cognitive strategy and 5.5 for socio-affective strategy (see also appendix 13).

The data also suggest the overal increase in term of strategy engagement from the first meeting to last meeting of the second circle. The averall increase of the strategy involvement was $30.3 \%$. While for the individual strategy category, the increase of meta-cognitive strategy was $29.1 \%$, cognitive strategy was $28.3 \%$ and the socio-affective strategy was $24.3 \%$.

\section{Discussion}

The result of the study suggests that in the initial phase of the treatment, the students had already applied some strategy in listening. It was proven by the average scores of their SIQ data which revealed that their strategy implementation in listening was in the medium level. By introducing the SBI, the level of the students' strategic investment in listening increases up to 30 percent; increasing to high level. The increase include all aspects of the strategy; metacogitive, cognitive and socio-affective strategy. Although the average score of the individual aspects vary, the increase was steadily applied to all of those aspect.

In addition, the study also indicates that the students' familiarity of the terms were shown improved. The think aloud protocol which reveals students' understanding of particular strategies in listening was elaquontly elaboration. They can tell their process of listening using the already taught strategies and provide reflection on what aspects and parts of listening they did well and least successful.

The study also reveals that the increase in strategy engagement is also followed by the increase in students' score in comprehension. The increase of average score even greater than the average score of their strategy 
engagement. Although many aspects of learning may contribute to the increase of students' comprehension, the contribution of strategy engagement is inevitably remarkable.

This finding confirms the available array of literature that SBI may improve the quality of learning in many different contexts. Vandergrif (2004) suggest that using metacognitive strategy, the average score of the high school students in listening comprehension was higher as due to the implementation of the metacognitive strategy. Liu and Goh (2006) also indicate that students' improvement in listening were also raised due to the implementation of strategy instruction in Singapore. Finally, this study supports the learning principle suggested by Brown that "succesful mastery of the second language will be due to a large extent to a learner's own personal investment of time, effort, and attention to the second language in the form of an individualized battery of strategies for comprehending and producing the language" (p.69).

\section{REFERENCES}

Bacon, S. M. (1992). Authentic listening in Spanish: How learners adjust their strategies to the difficulty of the input. Hispania, 75(2), 398412.

Burns, R. B. (1995). Introduction to Research Methods. Melbourne: Longman Australia Pty Ltd.

Carrier, K. A. (2003). Improving high school English language learners second language listening through strategy instruction. Bilingual Research Journal, 27(3), 383-411.

Chamot, A. U. (2005). Language learning strategy instruction: Current issues and research. Annual Review of Applied Linguistics, 25, 112-130.

\section{CONCLUSION}

Learning from the findings of the study, it can be concluded Strategy Based Instruction can increase the students' engagement in listening. The overal increase of the strategy engagement throughout this study was $30.3 \%$. While for the individual strategy category, the increase of meta-cognitive strategy was $29.1 \%$, cognitive strategy was $28.3 \%$ and the socio-affective strategy was $24.3 \%$.

In addition, the increase in not only on the strategy involvement, but also improvement in term of students' comprehension of the listening input. The increase of student' mean score from 4.7 in the to pre test up to 7.3 in the post test. This score indicate that the increase in students' achievement was around 53\%. It suggests that that the increase in strategy involvement coincides with the increase in students' achievement.

Chen, Y. (2007). Learning to learn: the impact of strategy training. ELT Journal, 61(1), 20-29.

Cross, J. (2009). Effect of listening strategy instruction on news videotext comprehension. Language Teaching Research, 13(2), 151-176.

Field, J. (1998). Skills and strategies: towards a new methodology for listening. ELT Journal, 52(2), 110118.

Field, J. (2000). Not waving but drowning: a reply to Tony Ridgway. ELT Journal, 54(2), 186195.

Gay, L.R., and Airasian, P. (2000). Educational reseacrh; 
Competencies for Analysis and Application. six edition. New Jersey: MERRILL

Goh, C., \& Taib, Y. (2006). Metacognitive instruction in listening for young learners. ELT Journal, 60(3), 222-230.

Goh, C. C. M. (1998). How ESL learners with different listening abilities use comprehension and tactics. Language Teaching Research, 2(2), 124-147.

Liu, X., \& C.M.Goh, C. (2006). Improving second language listening: Awareness and involvement. In T. S. C. Farrell (Ed.), Language teacher research in Asia. Alexandria, Virginia: TESOL, Inc.

Moleong, L. J. (2006). Metode Penelitian Kualitatif. Bandung: PT Remaja Rosdakarya.

O'Malley, J. M., Chamot, A. U., \& Kuper, L. (1989). Listening comprehension strategies in second language acquisition Applied Linguistics, 10(4), 418-437.

Oanh, D. T. H. (2006). Learner autonomy in an Asian context: Independent learning and independent work at the university level. In T. S. C. Farrell (Ed.), Language teacher research in Asia. Alexandria, Virginia: TESOL, Inc

Oxford, R., \& Crookall, D. (1989). Research on language learning strategies: Methods, findings and instructional issues. The Modern Language Journal, 73(4), 404-419

Ridgway, T. (2000). Listening strategiesI beg your pardon? ELT Journal, 54(2), 179-185.

Rubin, J. (1994). A review of second language listening comprehension research The Modern Language Journal, 78(2), 199-221.

Sheerin, S. (1987). Listening comprehension: teaching or testing? ELT Journal, 41(2), 126.

Syamsudin, \& Damajanti, V. S. (2006). Metode Penelitian Pendidikan Bahasa. Bandung: PT Remaja Rosdakarya.

Thompson, I., \& Rubin, J. (1996). Can strategy instruction improve listening comprehension? Foreign Language Annals, 29(3), 332-343.

Vandergrift, L. (1999). Facilitating second language listening comprehension: acquiring successful strategies. ELT Journal, 53(3), 168-176.

Vandergrift, L. (2004). Listening to learn or learning to listen? Annual Review of Applied Linguistics, 24, 3-25.

Vogely, A. (1998). Listening comprehension anxiety: Students' reported sources and solution. Foreign Language Annals, 31(1), 67-80. 